\title{
O CORPO MORTO Mitos, ritos e superstições
}

\author{
Moisés de Lemos Martins \\ Universidade do Minho, Portugal
}

\begin{abstract}
Resumo: Este estudo tem um cariz preponderantemente sócio-antropológico, versando as tradições, as crenças, os mitos, os ritos, enfim, o modo como a comunidade humana imagina o post mortem e cuida de alguém que morreu. No entanto, depois de uma rápida digressão histórica sobre a morte no Ocidente, tomando como fonte obras de Philippe Ariès (1975 e 1977), Louis-Vincent Thomas (1985), e Maria Manuel Oliveira (2007), o meu propósito visa sobretudo a contemporaneidade, onde as transformações operadas na cultura pelas tecnologias e pelos media, de tão profundas, vieram alterar, ao longo do século XX, o sentido que tanto damos à vida como à morte.
\end{abstract}

Palavras-chave: rituais de morte, cultura visual, trágico, grotesco, barroco

\section{No corpo morto está sempre o que socialmente somos}

\section{A morte domesticada}

O meu ponto de partida é o século IX de Carlos Magno e a sociedade rural tradicional. Nessa época, sabe-se que vamos morrer; assim como também se sabe quando se morreu. Doente ou ferido, o cavaleiro carolíngio deita-se ao comprido, junta as mãos, vira a calote do crânio para Jerusalém, faz uma lamúria pelas coisas da vida, pede perdão aos amigos pelas faltas que teve, recebe o perdão e encomenda a alma a Deus. $\mathrm{O}$ seu corpo irá repousar debaixo do soalho de uma igreja, ou então num cemitério, nas suas cercanias.

Esta prática medieval, que coloca o cemitério no centro eclesial da aldeia, exatamente como a morte está no centro da vida, traduz uma rutura com as antigas tradições romanas. Tais tradições exilavam os cadáveres, que eram tabu, para longe do coração da cidade, para os arredores afastados, ou então para túmulos que ladeavam as estradas, fora da cidade. O corpo do cavaleiro, todavia, depois de algumas dezenas de anos na sepultura, debaixo do soalho do santuário, será lançado na vala comum... a sua alma andará então errante por uns tempos ou voltará para junto dos vivos. Mas não tardará a regressar ao repouso, em que permanecerá até ao fim dos tempos, de onde apenas despertará, “ao som de trombetas”, no dia do juízo final. 
No que se refere às elites, as coisas mudaram depressa. Logo no século XII acontece uma primeira mutação cultural. É uma mutação que dá conta da lenta aparição do indivíduo e das biografias individuais, que evocam a morte de si. Já não se trata de “todos-os-que-morrem”, mas “de mim-próprio que morro”. Segundo Philippe Ariès (1977), este surto de individualismo afirma-se, primeiramente, na nova conceção do juízo. Já não se trata do final dos tempos, mas da justiça última. Cristo, a Virgem, São João e os Anjos são constituídos como juízes soberanos, e também como medianeiros. Armados de gigantescas balanças, cabe-lhes separar os eleitos para um lado e os condenados para outro. Entretanto, a cena da preparação para o além individualiza-se ainda mais, quando a grande parada da justiça, exibindo as balanças e toda a parafernália do juízo, é transportada para o quarto do doente, e colocada por cima do leito de morte do agonizante. Dispomos, sobre este assunto, de uma abundante iconografia medieval. O interessado tem tempo para fazer um balanço quase comercial da sua biografia, dos seus feitos e gestos, bons ou maus. E enquanto isto acontece, a tumba personaliza-se. As sepulturas passam a sobressair no recinto da igreja, ladeando-a. O uso romano do epitáfio, que havia sido esquecido durante a alta Idade Média, volta a ser atual, a partir da época gótica. E as lajes funerárias cobrem-se de estátuas ou de baixos-relevos.

Nos séculos XIV e XV, o homem das classes superiores já não considera a sua existência como um destino. Deitar-se para morrer, no termo de uma viagem inelutável, poderia estar bem para o cavaleiro carolíngio, mas não para si. O mercador da Flandres ou de Paris, do fim da Idade Média, projeta a sua vida como uma promessa de felicidade, todavia abruptamente interrompida pela morte - um sabor amargo que o penetra e lhe arruína a liberdade criadora. A morte, nesta empreitada, é de facto um frustrante e perturbador acontecimento. Porque o dobra e quebra. Deste infausto acontecimento decorre a amargura da derrota, na hora do balanço final, e também o horror fascinado que se sente pelo cadáver em decomposição. Vemos este horror fascinado, por exemplo, na pintura da Baixa Idade Média, uma época flagelada pela peste em massa.

No século XVII impõe-se a morte barroca, provavelmente um dos maiores êxitos estéticos que o Ocidente realizou no que se refere à arte de morrer e de ser enterrado. A inumação barroca unifica o individual e o social; aceita os factos macabros, mas não as suas versões neuróticas, centradas na putrefação. A morte barroca responde às preocupações que então surgem no que respeita à alma do falecido. Ao som dos sinos, a morte barroca reconstitui as hierarquias sociais, enfim, a ordem social da cidade, de pobres e privilegiados (Oliveira, 2007). Trata-se de uma ordem pomposamente 
recomposta, no decurso da procissão fúnebre que acompanha um enterro de luxo, atrás de desenhos de cabeças de morte e de lágrimas, bordados em pano.

No entanto, a ave agoirenta, que parecia tão bem domesticada, acabou por escapar da gaiola. De novo levantava voo essa sinistra coruja. Assinala Ariès, que, sobre este aspeto, o século XIX começa por volta de 1780, no tempo do pintor Jean-Baptiste Greuze, com os seus melodramas chorosos. Os tempos são então portadores de uma certa morte romântica, uma morte vivida, apaixonada, emocional e histericamente, pelas pessoas chegadas do falecido. Numa palavra, já não se trata da morte de si, nem da morte do outro, irmão, cônjuge, ser amado... A emoção diante da morte de outrem pode atingir o erotismo macabro, um erotismo preparado por uma tradição que vai do pintor Hans Baldung Grien (século XVI) ao escritor Marquês de Sade (séc. XVIII/XIX).

Já antes da Revolução de 1789 que os quadros de Greuze dão o tom. Trata-se de pinturas banhadas em lágrimas. Mas o que vai acontecer, depois de 1850, é o estabelecimento, em cemitérios monumentais, de um fantástico culto familiar e cívico aos mortos, que junta cristãos de todas as cepas e positivistas laicos. Espetaculariza-se a morte, convertida em motivo de fabulosos "museus ao ar livre" (Oliveira, 2007). Em França, o Père-Lachaise é o arquétipo deste tipo de cemitérios monumentais. E vêm a caminho os monumentos aos mortos das guerras mundiais.

Finalmente, a morte no nosso tempo. Relegado para o hospital, eriçado de aparelhos tubulares, o moribundo é evacuado do social, deixando de presidir à encenação da sua agonia e da sua morte, ao contrário do que havia acontecido desde a época carolíngia. Os últimos instantes, a missa fúnebre e a inumação, são atos sociais realizados à pressa, e mesmo com alguma ligeireza. Como bem refere Thomas (1985: 37), "a crise do ritual está em estreita conexão com as ideias-força da civilização técnica”. Todos os funerais se assemelham na sua insignificância, com a exceção siderante do funeral das estrelas mass-mediáticas, quaisquer que sejam os géneros: Princesa Diana (1997), Papa João Paulo II (2005), Ayrton Senna (1994), Niklas Fehér (futebolista húngaro do Benfica, falecido em 2004, no campo de jogo, em direto, na televisão), Michael Jackson (2009). A extrema-unção havia sido, em tempos, uma preparação solene para o Além. Hoje, não passa de um simples "sacramento dos doentes" - ou seja, um antibiótico espiritual. As famílias continuam a juntar-se à roda das sepulturas, esplendidamente floridas, no dia de Todos os Santos. Mas a sociedade laicizou-se, tornou-se profana.

Com a laicização, desenvolveram-se, entretanto, as novas práticas dos funeral directors e dos funeral home, que concretizam os cuidados da tanatopraxia e da tanato-estética (Thomas, 1985: 98-101). Estas artes contemporâneas de maquilhagem da violência da 
morte, que a amansam enquanto a domesticam, sossegam-nos sobre a sua inelutabilidade. Tratado segundo as técnicas da tanatopraxia, o morto parece dormir apenas o sono dos justos. A tanato-estética tem-se justificado, com efeito, pela necessidade de combater o caráter macabro de que a morte se reveste em certos casos especialmente violentos, por exemplo em resultado de acidentes vasculares cerebrais, de acidentes rodoviários e de doenças oncológicas. Lembremos Godfather, o filme que Francis Coppola realizou em 1972. Dom Corleone pede ao cangalheiro a reconstituição do rosto do filho, Santino Sonny Corleone, esmigalhado à bomba, num assassinato. A razão invocada era a de evitar que a mãe, ao velar o filho, pudesse ficar chocada diante do espetáculo macabro da morte.

Mas, apesar de este ritual laico de preparação estética dos cadáveres poder ser considerado sob o signo da esperança e da pacificação, embora esta cosmética tenha um caráter fúnebre e a maquilhagem um gosto duvidoso, podemos, igualmente, encarálo pelo lado grotesco, nos termos em que Bakhtin (1970: 29) o caraterizou, de uma transposição de "todos os cerimoniais e ritos para o plano material e corporal”. De acordo com Bakhtin (Ibidem), todas as formas grotescas "rebaixam, aproximam da terra, corporalizam”. O rebaixamento do sublime não significa, todavia, em Bakhtin (1970: 30), relativismo, consiste antes "em aproximar da terra, compreendida como um princípio de absorção, e simultaneamente de nascimento: rebaixando, sepultamos e ao mesmo tempo semeamos, damos a morte para logo a seguir darmos uma vida melhor e mais abundante".

\section{A vertigem, a crise, o risco, o fim}

É um sentimento de época a sensação de que o nosso tempo já não exprime uma sociedade afortunada, ou providencialista. Por um lado, a perceção do risco, do perigo e da crise mantém-nos em constante sobressalto e desassossego. Por outro lado, a sociedade vive em permanente flirt com a morte. Dessacralizada e laica, a sociedade junge, com efeito, a todo o tempo, thanatos e eros.

É também um sentimento de época que a passagem do regime da palavra ao regime da imagem tecnológica nos deixa "em sofrimento de finalidade" (Lyotard, 1993: 93). A palavra havia inscrito o Ocidente numa história de sentido, entre uma génese e um apocalipse. O regime da imagem tecnológica é um regime autotélico de sentido, de imagens profanas e laicas.

Em vez da cruz redentora de Cristo a iluminar-nos, temos agora os holofotes das grandes paradas mediáticas, uma luz de cuja artificialidade nos damos conta quando a corrente elétrica falha. Precipitados na imanência, estamos marcados, com efeito, pela 
instabilidade e o desassossego. A pulsão de vida entra em permanente diálogo com a morte, sendo melancólicas as luzes dos holofotes, que não passam de sombras de um astro morto.

No regime da palavra, os rituais de celebração da morte eram rituais de passagem, mediando entre esta vida e a outra. Pacificavam a passagem, por difícil que fosse, porque o caminho se inscrevia numa história da salvação. A narrativa dos rituais de passagem é dramática, pois é animada por uma síntese redentora. A nossa passagem imitava e repetia, com efeito, a encarnação de Cristo, uma passagem terrena, que compreendia sofrimento, morte e ressurreição. É esse, aliás, o ensinamento da Ars moriendi, uma literatura e catequese cristãs, escritas no século XV para preparar a boa morte. Porque não existe cruz sem ressurreição.

No entanto, no regime da imagem de produção tecnológica, que integra o atual sistema mediático, os rituais de celebração da morte já não são rituais de passagem, dado que não constituem a mediação desse acontecimento soberano, que é a passagem para o "reino dos justos”. Na era mediática não temos passagens; pelo simulacro televisivo, énos dado a ver, em direto, o próprio acontecimento. A morte em direto faz equivaler a morte de todas as tragédias coletivas, e também a morte de todas as personalidades, assim como a morte do cidadão comum, no uso dos seus quinze minutos de fama, assinalados por Andy Warhol. Testemunhado e vivido por nós, em direto, o acontecimento é nosso. Assim como também o é a tragédia. A narrativa mediática da morte constitui, é verdade, uma intérmina glosa à condição humana: sempre com a morte nos olhos, vivendo em permanente tensão ${ }^{1}$.

Como assinalei, esta narrativa já não é dramática, mas trágica, constituindo uma travessia perigosa e sem controlo. O conto é sempre o mesmo: nenhuma síntese redime o acontecimento. O destino impõe-se, sem verdadeira saída, pela mão da Al Qaeda (atentados de Nova Iorque, Londres, Madrid), pela mão da doença (Alzheimer, no caso do Papa João Paulo II), dos paparazzi, no caso da Lady Di, de provável overdose, no caso de Michael Jackson. É trágico o império do direto e do imediatismo noticioso, que nos impõe um eterno presentismo, sem síntese redentora.

Porque se trata de uma narrativa híbrida, cheia de sombras, de enredo labiríntico e enigmático, e presidida pelo pathos (pela sensação, emoção e paixão), a narrativa mediática já não segue o cânone clássico, antes é barroca e grotesca. É barroca a

\footnotetext{
${ }^{1}$ Sobre os imaginários sociais, que produzem o acontecimento-catástrofe, e também sobre a influência que o acontecimento-catástrofe tem nas opiniões, atitudes e comportamentos de prevenção do perigo e nas representações sociais da segurança, Bertrand Vidal defendeu uma tese de doutoramento, na Universidade Paul Valéry - Montpellier III, em dezembro de 2012. E é clássica, neste contexto, a obra de Henri-Pierre Jeudy: Le désir de catastrophe (1990).
} 
narrativa da morte na sua encenação mediática. Prolonga-se pelas pregas de um ritual que na monotonia da repetição permanente das mesmas imagens, não constitui nenhuma superfície lisa e clara, que permita iluminar o enigma e o labirinto do enredo - retraída e dolente a razão, existe uma espécie de estupor que nos deixa em estado de choque e nos paralisa. Trata-se de uma superfície cheia de concavidades, que mantém o enigma da nossa vida.

É, com efeito, grotesca a narrativa dos media sobre a morte. Pela total inversão dos valores. São moralmente monstruosos os atentados terroristas às Torres Gémeas de Nova Iorque (2001). É grotesca a violência da visão dos corpos decepados, esquartejados e expostos em pedaços, sem pudor, pela via férrea de Atocha, em Madrid (2004). E do mesmo modo os corpos a apodrecer no areal da praia, no caso do tzunami da Ásia (2004). “O que é que você sentiu?” “E o que é que agora está a sentir?” insistem os jornalistas. São grotescas as suas entrevistas, que esventram toda a intimidade, intimando as vítimas a partilhar a dor com a "humanidade", que uma câmara de televisão proporciona (Oliveira, 2005 e 2008). É grotesca a filmagem da morte de Ramon Sampedro, que decidiu filmar a cena da prática de eutanásia com que pôs termo à vida, em 2004, fixando-a em imagens para todo o sempre. No ecrã, o gesto repete-se e prolonga o instante em eternidade.

$\mathrm{Na}$ narrativa tradicional, a hora da morte vem pela calada e apanha-nos na mais completa solidão. Se é partilhada, apenas acontece com familiares próximos. Não é provocada. E muito menos é um ato provocatório, que repita a transgressão para a eternidade. Mas já não é assim com a narrativa mediática. Nada tem de sublime o sofrimento do Papa João Paulo II, esventrado na TV. Pelo contrário, é grotesca a exibição da sua agonia - a de um moribundo ambulante. E é igualmente grotesco o colossal amontoado de flores, aquando da morte de Diana de Gales, em 1997, tanto na Ponte d'Alma, em Paris, como junto à cerca do Palácio de Kensington, em Londres. E da mesma forma é grotesco o luto dos pais de Maddie McCaan, a menina inglesa desaparecida no Algarve, em 2007, não se sabendo, ainda hoje, se raptada se morta, um luto exibido de conferência de imprensa em conferência de imprensa, entre Portugal e o Reino Unido, durante mais de dois anos.

A reportagem jornalística da morte subverte, é um facto, os códigos jornalísticos. Com efeito, a exacerbação das emoções, colocando o logos e o ethos sob o domínio do pathos, desclassifica o jornalismo, que "come o pensamento", como se lhe referiu, Karl Kraus, há um século. 
Neste contexto, é importante assinalar a alteração cultural referida pelo filósofo e antropólogo Marcel Gauchet (1985), de que a religião não estrutura mais a vida nas sociedades contemporâneas, que são laicas, profanas, no seu funcionamento. O que significa que já não acontece as sociedades modernas viverem segundo o regime da analogia, com as cidades dos homens a remeterem para a cidade de Deus. Os humanos estão hoje precipitados no mundo, numa travessia intérmina e labiríntica, sofrendo a contingência, a instabilidade e a imprevisibilidade de um destino que aflige a vida humana. Chamados a afrontar os perigos e a correr os riscos desta intérmina travessia em que o humano se decide, é a morte que temos sempre diante dos olhos.

A civilização moderna tem-se deslocado "dos átomos para os bits" (Negroponte), da palavra para a imagem, do "sun/bolé para a dia/bolé", da palavra para o número, "das estrelas para os ecrãs” (Virilio, 2001: 135), do uno para o múltiplo. Em grande medida, refiro-me às consequências da imersão da técnica na vida e nos corpos, uma imersão que dá azo à deslocação da ideologia para a sensologia (das ideias para as emoções); à deslocação de uma sociedade de fins universais para uma sociedade de meios sem fins (com a tecnologia a sobrepor-se aos princípios teleológico e escatológico na história e a desmantelar o fim de uma história com génese e apocalipse, impondo-nos o presentismo e o instantaneísmo); enfim, refiro-me à deslocação da história no sentido da sua aceleração infinita e da mobilização total do humano (Virilio, 1995; Sloterdijk, 2000; Martins, 2010, 2011).

Entretanto, tem-se acentuado a ideia de crise do humano, à medida em que passamos a falar de vida artificial, de fertilização in vitro, de "barrigas de aluguer", de clonagem, replicantes e cyborgs, de adeus ao corpo e à carne, de pós-orgânico e de trans-humano. E também à medida que se desenvolve a interação humana através do computador, onde os chats da Internet, os jogos eletrónicos, e as novas redes sociais, como o SecondLife, o Facebook e o Twitter, por exemplo, instabilizam as tradicionais figuras de família e comunidade, para em permanência as reconfigurar. Acima de tudo, é a completa imersão da técnica na história e nos corpos que tem tornado problemático o humano. E são as biotecnologias e a engenharia genética, além do desenvolvimento da cultura ciberespacial, as expressões maiores desta imersão.

Nestas circunstâncias em que bíos e techné se fundem e em que a própria figura do homem se torna problemática, a palavra como logos humano entrou também em crise (Martins, 2009 e 2011). O homem deixou de ser «animal de promessa», como o havia definido Nietzsche (1887, II, § 1), porque a sua palavra já não é capaz de prometer. Onde ele se revê hoje é sobretudo nas figuras que acentuam a sua condição transitória, tacteante, contingente, fragmentária, múltipla, imponderável, nomádica e solitária. 


\section{Um imaginário com a morte nos olhos}

A alta cultura, a literatura, a pintura, a escultura e a música sinfónica, cederam o passo à cultura de massas, num processo que compreende as indústrias culturais e vê a obra de arte tornar-se mercadoria. Este vasto processo de civilização abarca a moda, o cinema, o turismo, as férias, e as empresas dos media, designadamente a imprensa, a rádio, a televisão, a Internet e a publicidade, e abarca, enfim, a cultura visual, o digital, os jogos eletrónicos.

A alta cultura era reificadora e elitista, alimentava-se da aura da criação e do ato original de um criador. Inscrevia-se numa narrativa, entre uma génese e um apocalipse e declinava uma história da salvação. Tinha um imaginário dramático, que compreendia uma síntese redentora, que dava sentido à vida inteira, incluindo o sofrimento e a morte: o reino de Deus, a suprema justiça, a sociedade sem classes, uma teologia da cruz, que levava à ressurreição. Tinha também um imaginário de formas clássicas, com uma razão esclarecida e iluminista a domesticar os demónios e a afugentar as sombras, todas as sombras, a impor sempre linhas retas e superfícies também sempre claras e transparentes. Tinha ainda um imaginário de formas sublimes, de formas elevadas, que sonhavam com a unidade e a totalização da existência humana.

A cultura de massas, que entretanto irrompeu entre nós, não tem génese nem apocalipse, vive o presente, "em sofrimento de finalidade", para retomar as palavras de Lyotard (1993: 93), e exprime o carácter labiríntico e enigmático do humano, uma condição fragmentária, instável, viscosa, sinuosa, finita e contingente.

A nossa atual situação resulta, em grande parte, do facto de a técnica ter investido a história e os corpos, a ponto de haver mesmo uma fusão de techné e bíos - daí a conversão da existência em experiência sensível.

O trágico é uma figura que vemos normalmente associada à literatura - é uma forma literária. O barroco é uma figura que assinala um movimento e um momento da história da arte ocidental. O grotesco é uma figura que exprime uma sensibilidade estética. Estas três formas são figuras avessas à ideia de totalização da existência, o que quer dizer, que são figuras avessas à sua ideia de perfeição e de harmonia. São figuras que declinam um destino sacudido pela vertigem do fragmentário, do marginal, do mundano e do profano, dando-nos a ver, além disso, o caráter viscoso, sinuoso, titubeante e labiríntico da condição humana. 
As formas do imaginário podem ter na cultura uma existência ostensiva, ou então discreta, ou ainda secreta. Na era dos media, o trágico, o barroco e o grotesco têm, a meu ver, uma existência ostensiva. Calabrese (1987) fala de uma "idade neobarroca"; Muniz Sodré e Raquel Paiva (2002), de um “império do grotesco"; Maffesoli (2000), de um "regresso do trágico".

Sabemos, desde Nietzsche, com efeito, e vemos Roland Barthes (1942), primeiro, e Michel Maffesoli (200o), depois, insistir neste aspeto, que o trágico se opõe ao dramático (num caso, temos contradições superadas por uma síntese - o dramático; noutro caso, temos contradições sem resolução do conflito - o trágico).

Por sua vez, Henrich Wölfflin (1991) assinala que o barroco se opõe ao clássico. Num caso, temos formas de linhas direitas e superfícies planas - o clássico; noutro caso, temos formas de linhas curvas, de dobras e de superfícies côncavas - o barroco.

E, de acordo com Mikhail Bakhtin (1970), o grotesco opõe-se ao sublime. Num caso, temos as formas de um mundo elevado, equilibrado e harmónico - o sublime; noutro caso, temos as formas desproporcionadas de um mundo rebaixado, invertido e desarmónico - o grotesco.

Estas três formas do imaginário, o trágico, o barroco e o grotesco, são dinâmicas e partilham caraterísticas semelhantes: em todas elas a vida e o mundo, embora palpitantes, são instáveis, ambivalentes, sinuosos, fragmentários, imperfeitos e efémeros. Mas também podemos assinalar diferenças. Desde a Contra-Reforma que o barroco se eleva da turbulência mundana às alturas das abóbadas e dos tronos, à procura de um acesso ao absoluto ${ }^{2}$. Por sua vez, o grotesco é voraz e corrosivo. Nada nele se salva, nem mesmo o absoluto. O sistema de valores é subvertido e macaqueado. O olhar grotesco rebaixa tudo o que atinge e precipita-o nos abismos da existência. No grotesco, a abertura devém cavidade, concavidade, prega, requebro, linha curva. Já o trágico entrega-se à vida com inquietude e melancolia, que são atitudes próprias de um ser que se empenha num destino incerto, sem nenhuma promessa de desenlace feliz. $\mathrm{O}$ trágico vive esta contradição: alimenta-se de uma certeza que lhe escapa sempre e esgota-se a promover impossibilidades, que imagina como eternidades.

Estamos, pois, diante de um imaginário melancólico, que exprime o mal-estar da sociedade e o sofrimento humano, que é também um sofrimento de finalidade, como já referi.

${ }^{2}$ Sem dúvida que o barroco se equivocou ao identificar o eterno, por um lado, com o poder absoluto dos reis, e por outro, com a dogmática e a catequese dos príncipes da Igreja. Benjamin (2004) denunciou, todavia, este "cadáver" humano. 
Nesta época, que o filósofo Ernst Jünger (1990: 108) classificou como "das máquinas e das massas", a morte e o prazer vivem lado a lado, num conúbio permanente. É esse conúbio entre thanatos e eros que, a traços largos, passo a analisar na cultura visual e mediática contemporânea.

\subsection{Representações da morte na publicidade}

Oliviero Toscani, fotógrafo que surpreendeu o mundo, trabalhando sobretudo para a Benetton, publicou em 1996 um livro emblemático com o seguinte título: A publicidade é um cadáver que nos sorri. Retomo quatro das suas criações, em que sobressai o caráter grotesco das formas rebaixadas ao inferno, de um mundo impuro, profano e laico, um mundo sem redenção, num processo que cria um efeito de desarmonia e ambivalência.

Imagem 1: A publicidade da Benetton toma a Sida como tema de uma campanha, em Fevereiro de 1992. Os familiares rodeiam o agonizante e fazem lembrar um quadro da paixão de Cristo, ou do Senhor morto, baixando da cruz. Trata-se de uma convocação impura, uma convocação grotesca da ars moriendi cristã, a descer aos infernos da mercadoria.

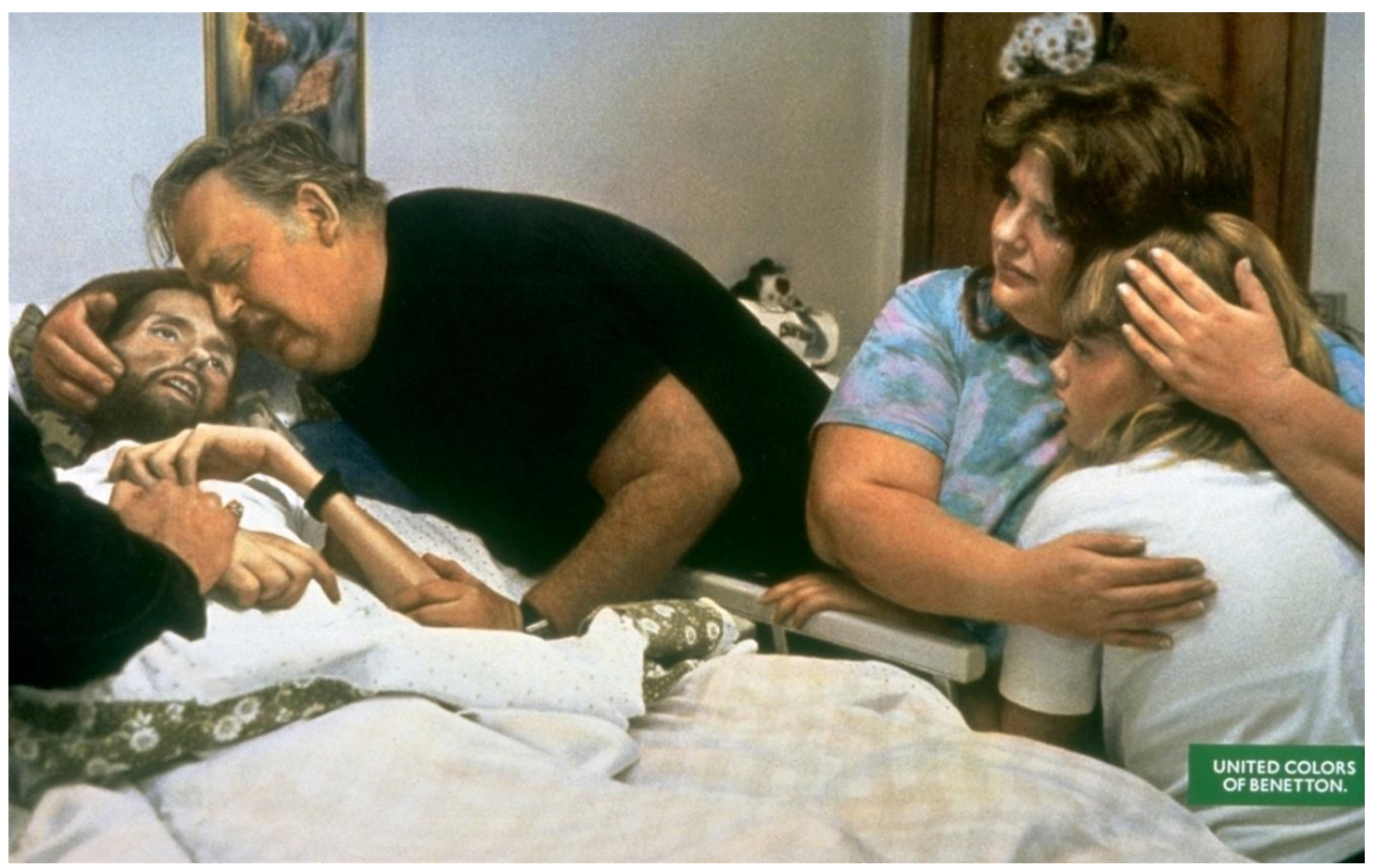

Imagem 1.'AIDS - David Kirb' - Campanha publicitária da Benetton, convocando a Sida | Fevereiro de 1992. Oliviero Toscani.

Imagem 2: A publicidade da Benetton convoca a cadeira eléctrica para tema de campanha, em Setembro de 1992. A cadeira eléctrica é um instrumento grotesco de justiça, porque é um aparelho de tortura e letal. 


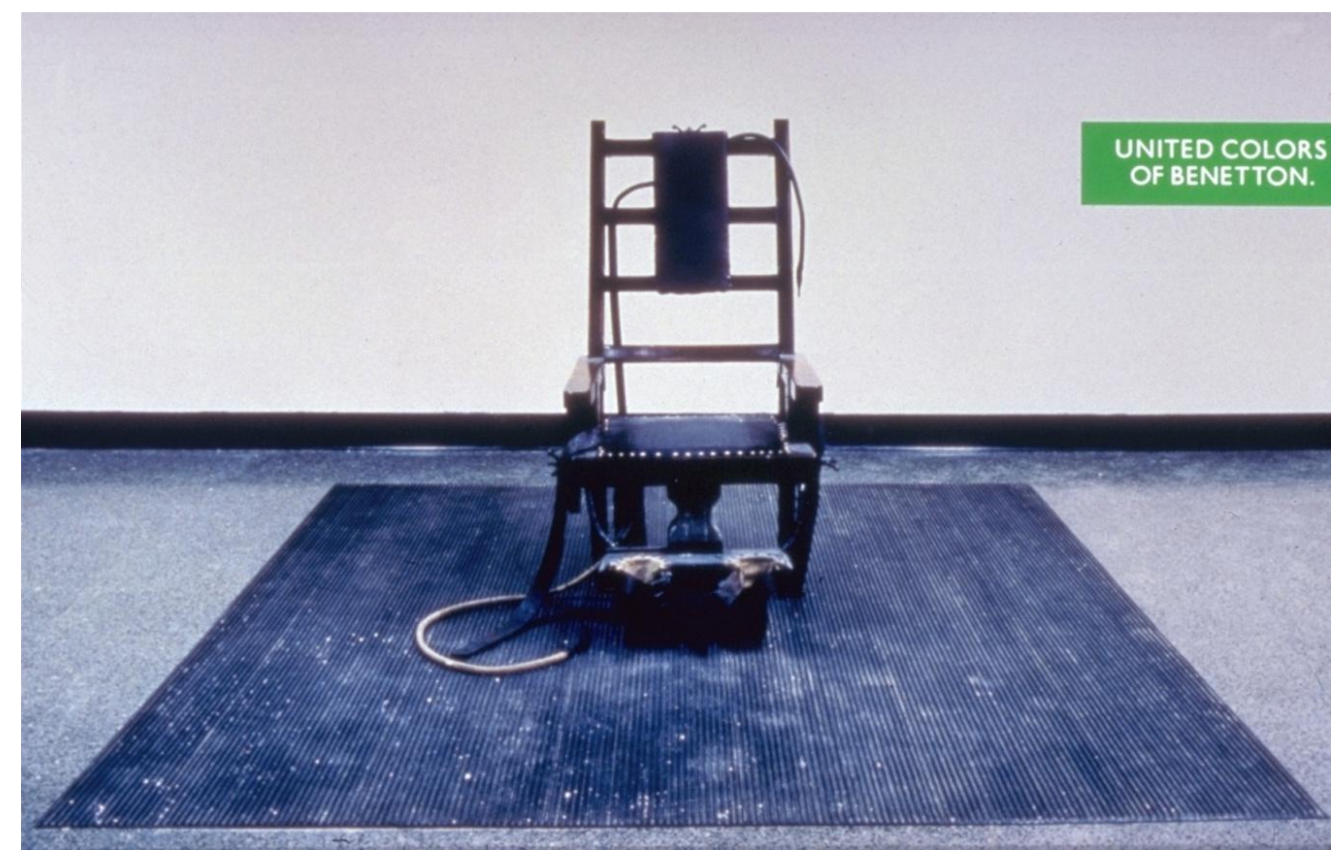

Imagem 2.'ElectricChair' - Campanha publicitária da Benetton, tomando como motivo a violência da morte na cadeira eléctrica | Setembro de 1992. Oliviero Toscani.

Imagem 3: A publicidade da Benetton toma como motivo para tema de campanha a violência bélica. "O soldado bósnio", de Fevereiro de 1994, combina as calças do camuflado de um soldado com uma t-shirt ensanguentada, onde se divisa, estampado em sangue, o rosto de uma jovem. O romantismo está, grotescamente, encharcado em sangue, numa convocação impura, que combina o amor com o sofrimento e a morte na guerra.

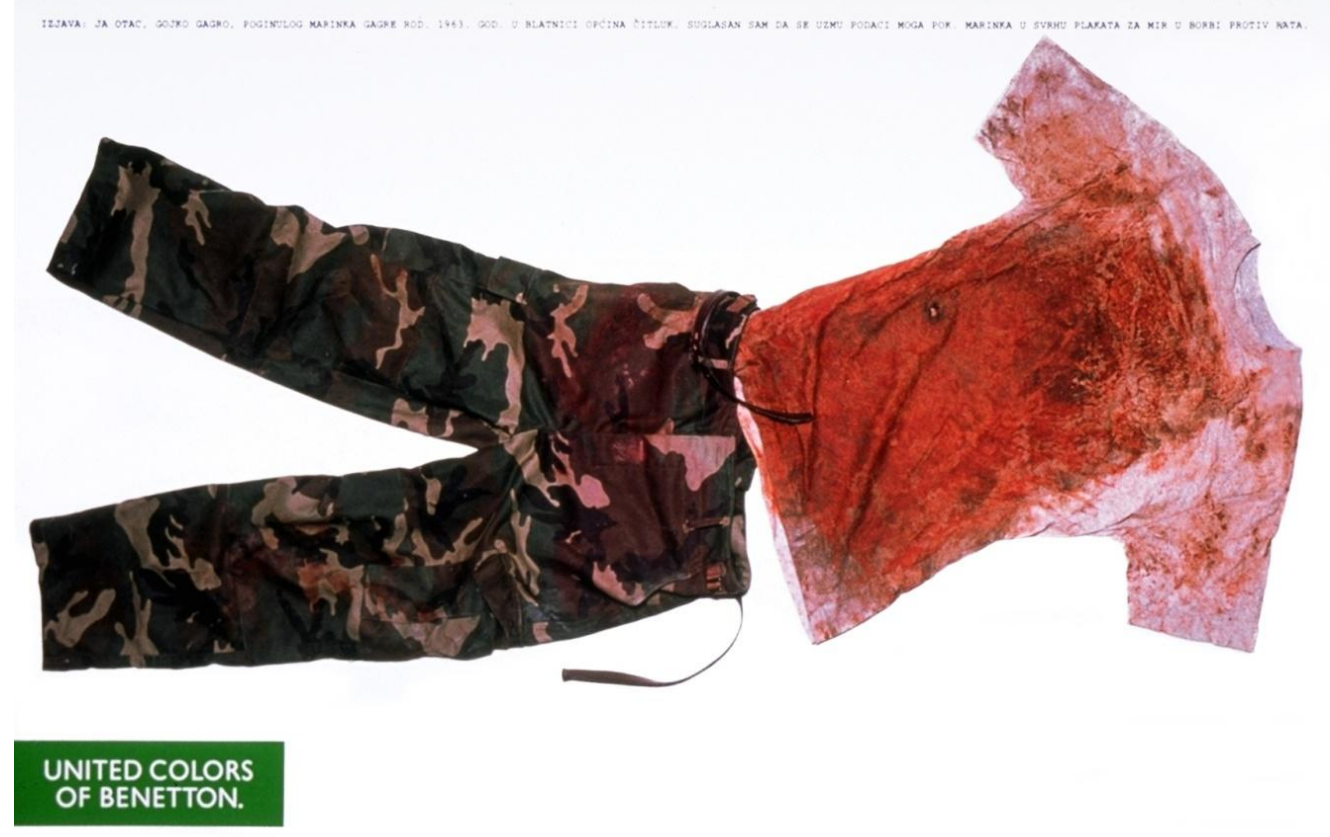

Imagem 3. 'Bosnian soldier' - Campanha publicitária da Benetton, convocando a guerra | Fevereiro de 1994. Oliviero Toscani. 
Imagem 4: A publicidade para Nolita, uma conhecida marca italiana de roupas de mulher, convoca, com escândalo, em Setembro de 2007, uma modelo anorética. Lembrando "Les fleurs du mal” baudelairianas, a modelo anorética integra uma estética nas antípodas dos códigos de beleza estabelecidos, uma estética que combina, grotescamente, com a ruína do corpo, o sofrimento e a morte.
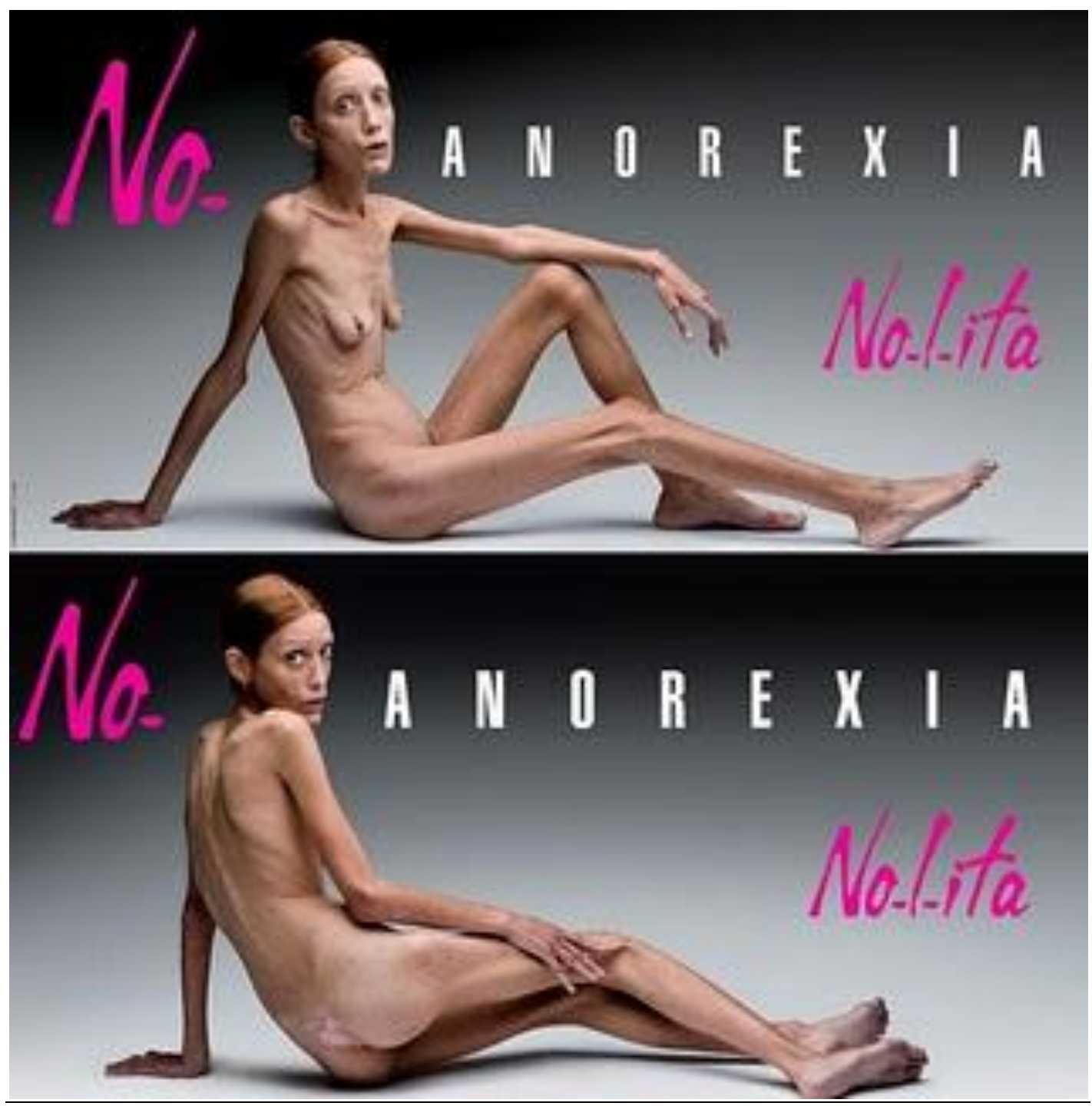

Imagem 4: Campanha publicitária com uma modelo anorética, realizada para a marca Nolita, em Setembro de 2007. Oliviero Toscani.

\subsection{Representações da morte na moda}

Alexander McQueen, estilista britânico que se suicidou em Fevereiro de 2010, é um estilista-fetiche dos desfiles de moda fúnebres. Convoco um conjunto de imagens dos seus desfiles de moda. 
O barroquismo e a desarmonia das formas, além da predileção por ambientes sombrios e de penumbra, caraterizam todas as imagens apresentadas. O cenário onde decorre o desfile é negro e as cores dominantes são o preto e o vermelho. Podemos associar este ambiente de obscuridade, tanto às trevas, como à morte e ao sangue. O contraste das formas grotescas e barrocas não pode ser mais manifesto, relativamente às formas sublimes e clássicas, que remetem para a claridade, a harmonia e as linhas direitas. Poderíamos mesmo referir que a morte é uma sugestão constante em praticamente todas elas.
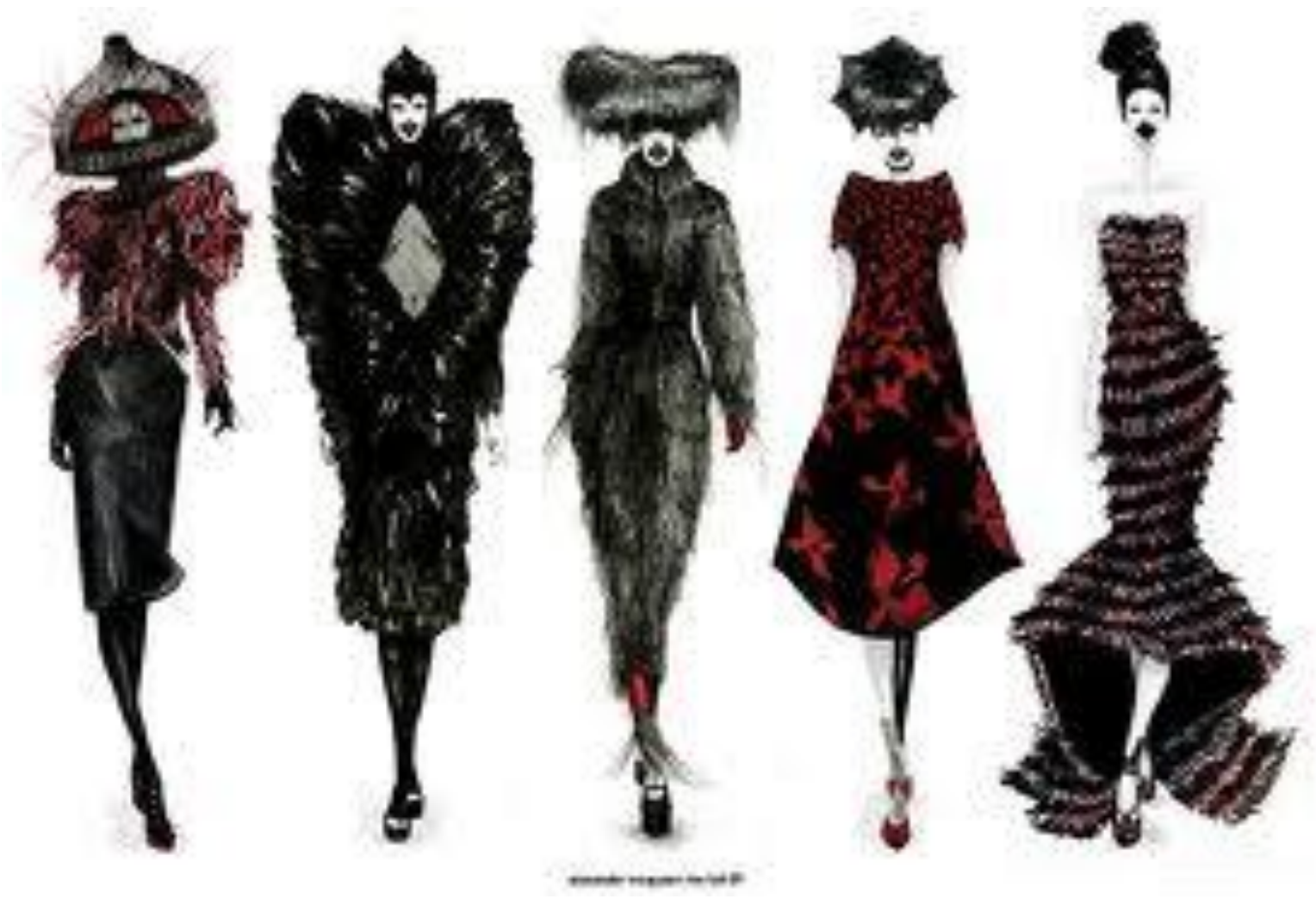

Imagem 5.Alexander McQueen. www.alexandermcqueen.com/

Esta primeira imagem convoca um universo de formas barrocas e grotescas, com espetros humanos envoltos em plumas e pregas, que mais fazem lembrar cadáveres maquilhados, ou então corpos em estado de decomposição, enfim, corpos vampirizados. A juntar ao caráter macabro das silhuetas está o seu caráter enigmático. Todas as silhuetas são aprisionadas por formas estranhas, que as agarram pela cabeça e quase lhes engolem os rostos. É sugerida uma realidade em transformação, mas de sentido desconhecido, embora, num caso, agoirado por bizarras formas de pássaro, estampadas no vestido; noutro caso, pela gaiola que converte a cabeça em estranha ave aprisionada; noutro caso ainda, pelas pregas, quais escamas encrostadas num corpo em forma de sereia; enfim, pelas formas de morcego com que é combinada a forma 
humana. Ou seja, a forma humana mistura-se com a forma inumana, de estranhos animais: morcego, sereia e pássaro. Os tons são sempre soturnos, próprios de um regime notívago, pintado a preto e a vermelho desbotado. Lembram farrapos negros, manchados de sangue. Os rostos caraterizam-nos a fealdade; mais parecem carrancas, ou então máscaras funerárias. Em todos estes espetros, que deambulam pela passerelle como zombies, ou mortos-vivos, a boca parece ter sido tocada pelo beijo da morte. As formas são longilíneas, mas multiplicam-se as sugestões de densas teias de aranha no toucado do cabelo, de asas de morcegos, de enxofre demoníaco e de corpos viscosos e em putrefação.

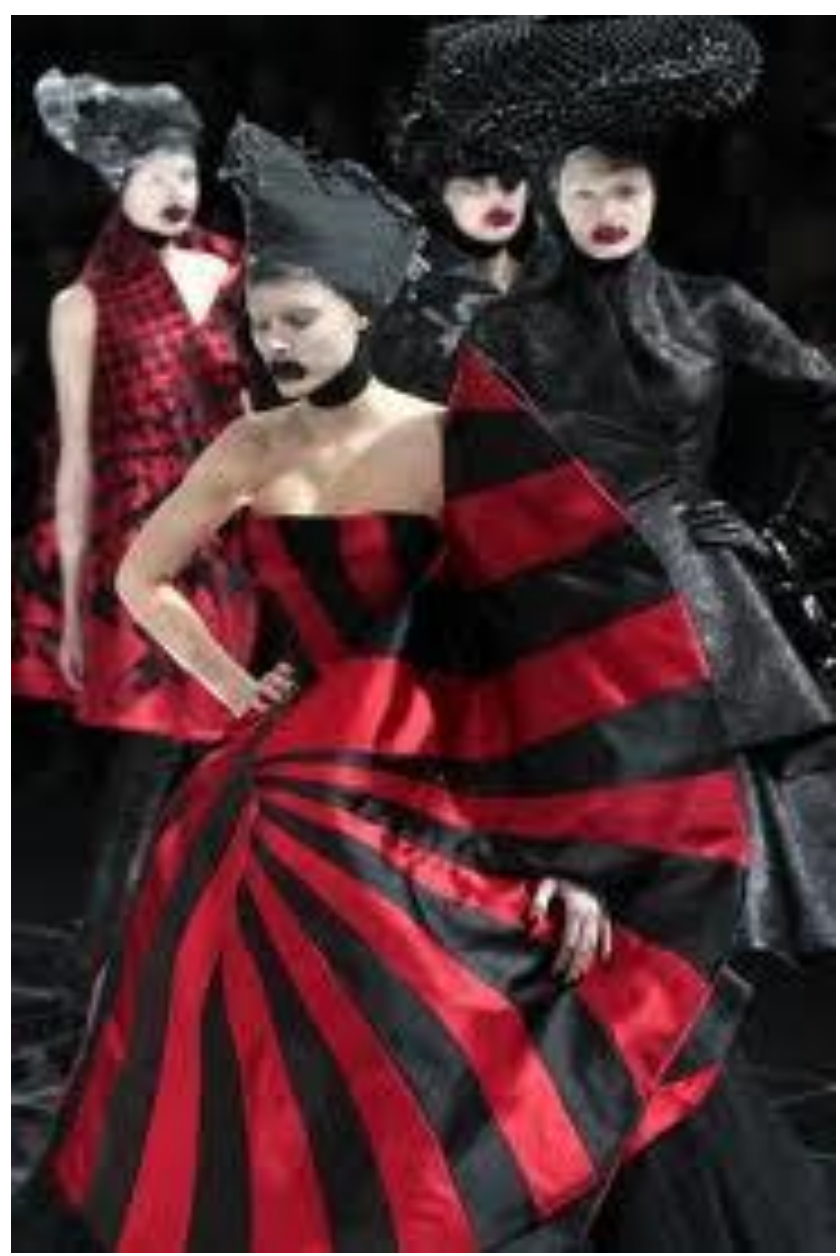

Imagem 6. Alexander McQueen. www.alexandermcqueen.com/

Nesta segunda imagem, os tons voltam a ser soturnos, a preto e vermelho, com o vermelho agora mais berrante, demoníaco. Permanecem os densos novelos de tecido, geralmente com pregas, a cobrir os cabelos, numa mistura de formas grotescas e barrocas. Os olhos estão envoltos em negrume, são buracos negros, como se de caveiras se tratasse. Os lábios, arrouxados, permanecem tocados pelo beijo da morte. Os rostos e 
a pele dos ombros ou dos braços, que espreitam dos generosos e exuberantes folhos e pregas da indumentária, exibem uma palidez doentia.

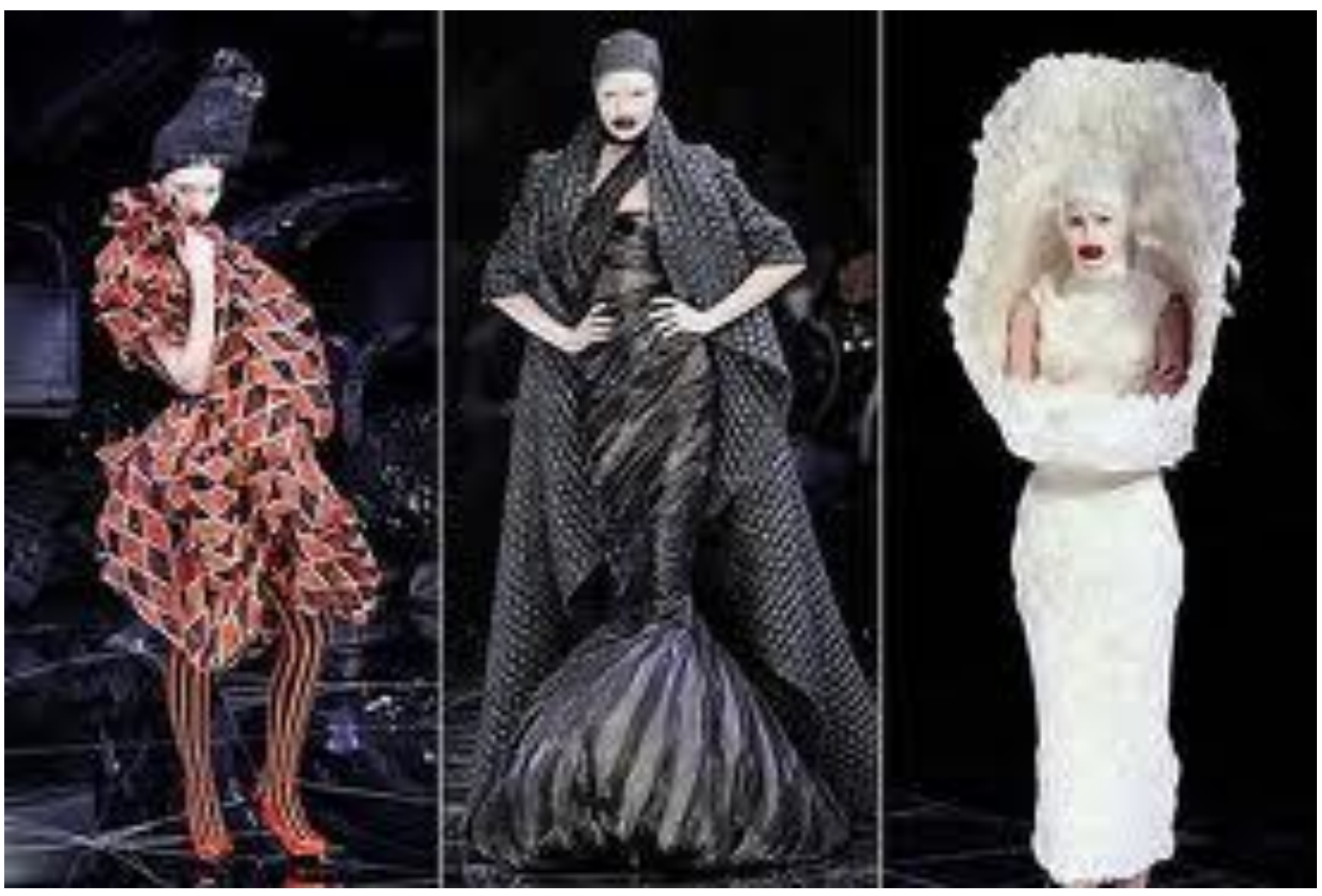

Imagem 7. Alexander McQueen. www.alexandermcqueen.com/

Nesta terceira imagem persistem, nas duas figuras da esquerda, a palidez doentia da pele, o negrume dos olhos, o beijo da morte nos lábios, os folhos e os tons de preto e vermelho desbotado, além da sugestão, um tanto satânica, da primeira figura. A terceira figura encena uma múmia, enfaixada de branco, como que pronta para a sepultura. As três figuras mantêm as características grotescas do seu carácter ambíguo, com a segunda e terceira figuras a sugerir um estado de transformação enigmático. 

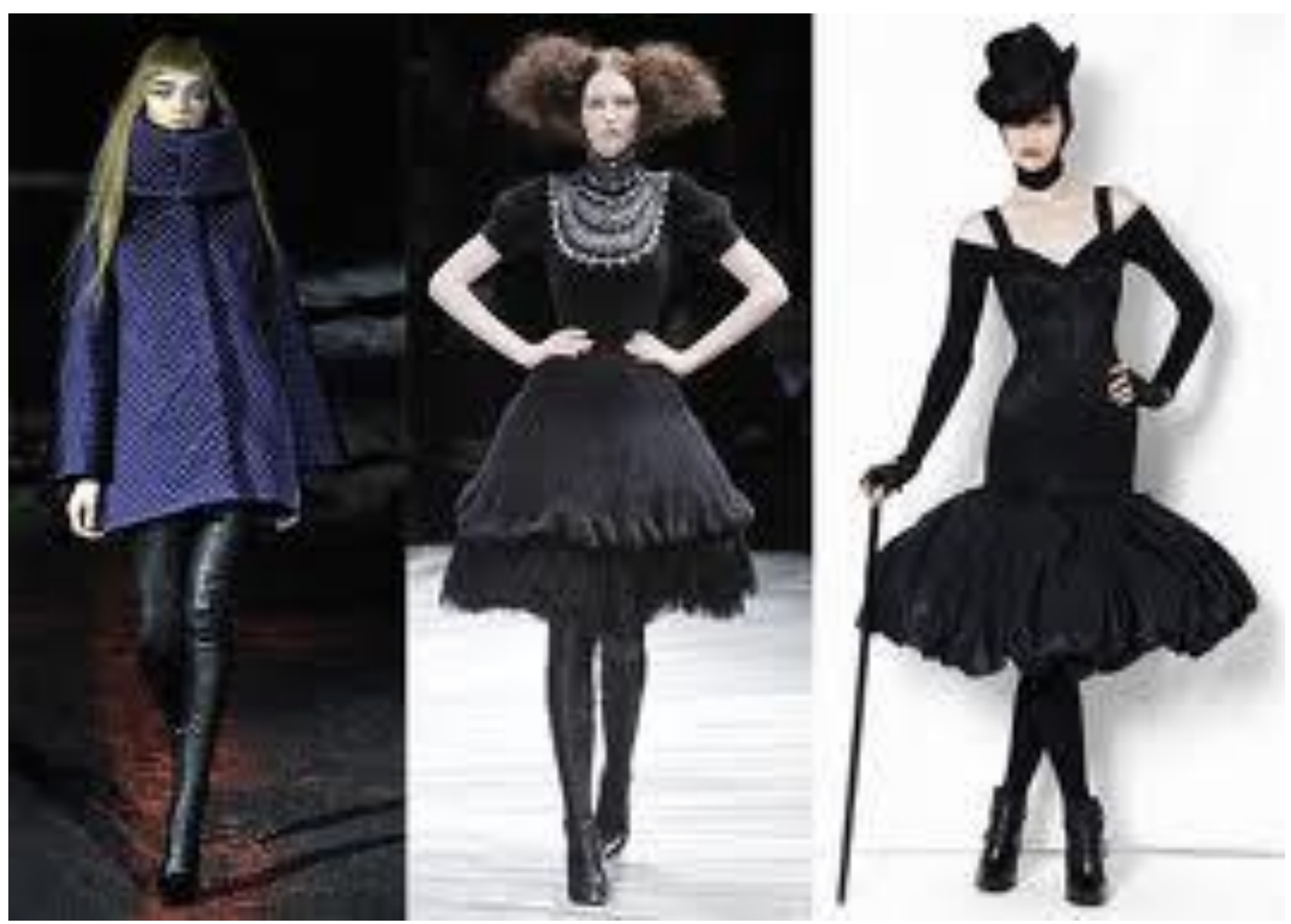

Imagem 8. Steve McQueen. www.alexandermcqueen.com/

A quarta imagem é uma composição de três modelos, com as caraterísticas de todos as outras já analisadas. As modelos glosam bem o título de Oliviero Toscani sobre a publicidade: também podemos dizer da moda, com propriedade, que ela é um cadáver que nos sorri. Ocorre nestas figuras um manifesto caráter grotesco, sublinhado no rebaixamento dos cânones estéticos: a palidez excessiva da pele; os cabelos escorridos num rosto cadavérico, ou então, como dois tufos desgrenhados, a acentuar a fealdade de um rosto exangue; e, finalmente, as cores preta e roxa, e ainda, vermelha, qual mancha de sangue. Nota-se, igualmente, o caráter barroco dos folhos e das pregas do vestuário. 


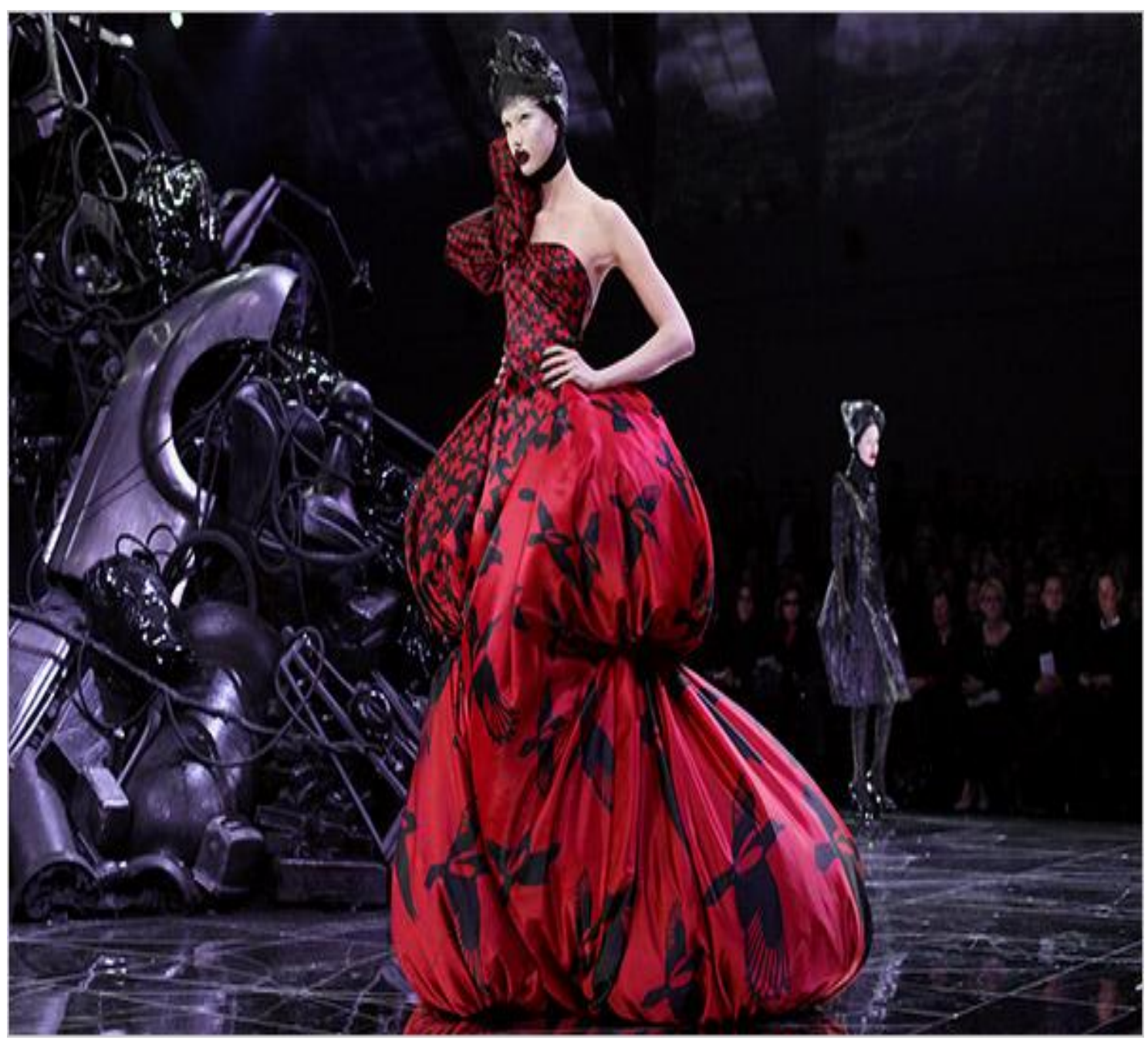

Imagem 9. Alexander McQueen. www.alexandermcqueen.com/

A figura localizada em primeiro plano é melancólica e enigmática, dado o barroquismo e o caráter grotesco das suas formas. A pele do rosto é de uma palidez excessiva, quase fantasmagórica, contrastando com o negrume dos lábios. Convocando a este propósito Bakhtin, dir-se-ia que se dá nesta figura a "transferência para o plano material e corporal”, que é o plano da terra e do corpo, na sua indissolúvel unidade, de tudo aquilo que é elevado, espiritual, ideal e abstrato (Bakhtin, 1970: 29). Ou seja, a figura humana representada nesta silhueta é percorrida pela ideia de ambivalência e o ideal de beleza é rebaixado. Dá-se, pois, nesta figura a assunção do realismo grotesco. Juntamente com a sugestão de ambivalência, a ideia de rebaixamento, de "mundo às avessas", de "paródia da vida comum" (Bakhtin, 1970: 19), preside ao realismo grotesco, constituindo ambos, ambivalência e rebaixamento, as suas principais caraterísticas. Como assinala Bakhtin (1970: 33), "A imagem grotesca carateriza um fenómeno em estado de transformação, de metamorfose ainda incompleta, um estado de morte e de nascimento, de crescimento e de evolução”. Na figura apresentada, ocorre a transformação do humano em algo indefinível. O rosto parece cativo de alguma coisa 
que o virá a engolir. É esta sugestão de aprisionamento das formas humanas, que todavia ganham matizes inumanos, ao misturarem-se com as coisas, que resulta em desarmonia, exagero, hiperbolismo e profusão, "sinais caraterísticos do estilo grotesco" (Bakhtin, 1970: 302).

Esta falta de harmonia e de proporção é particularmente visível no centro do cenário, composto por um conjunto de elementos amontoados, desarrumados, como se tivessem sido ali postos ao acaso, causando estranheza e interrogação no observador.
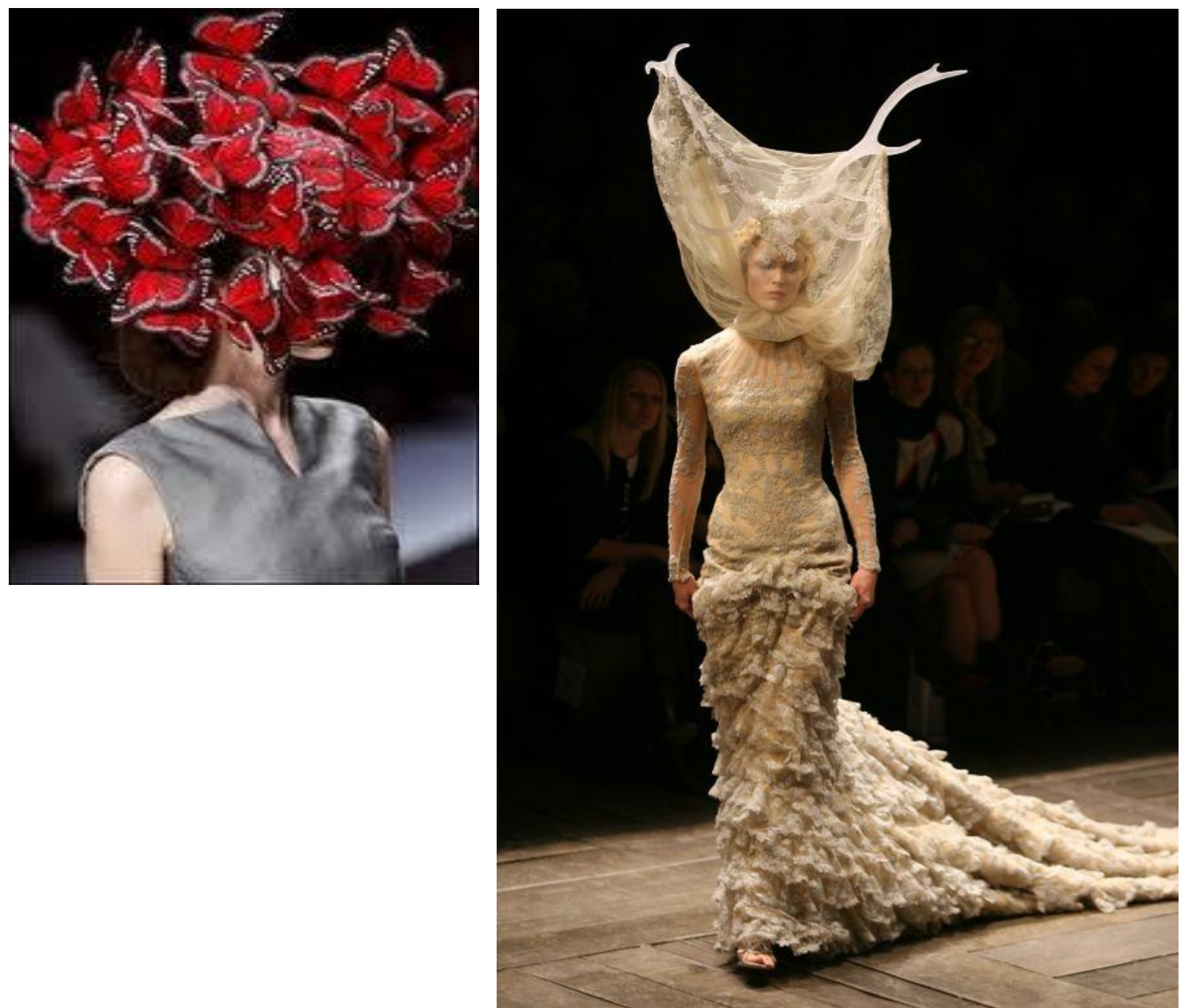

Imagem 10. Alexander McQueen. www.alexandermcqueen.com/

Nestas últimas figuras, o traço que mais se acentua é a hibridez do humano com as coisas e os animais. Aliás, pode dizer-se que "na base das imagens grotescas, encontrase uma concepção particular do conjunto corporal e dos seus limites. As fronteiras entre o corpo e o mundo, e entre os diferentes corpos, são traçadas de uma maneira completamente diferente às das imagens clássicas e naturalistas" (Bakhtin, 1970: 314). 
O caráter grotesco destas formas manifesta-se no facto de o animal invadir o humano, a ponto de se fundir com ele, dando origem a figuras monstruosas. Na primeira figura, a cabeça da modelo é engolida por uma revoada de borboletas. E quando a boca da modelo coincide com o pontilhado do rebordo das asas das borboletas, sobressai a sugestão de dentes numa caveira. Mas também podemos dizer que esse pontilhado figura a transformação da matéria numa nova vida, pela hibridez da forma de borboletas adultas com a sugestão de crisálidas no rebordo das asas. Por sua vez, a segunda figura lembra-nos um Minotauro, com as hastes de veado a enfeitar a cabeça da modelo. O manto que a cobre e o caudaloso vestido fazem-nos, entretanto, imaginar emaranhados de teias de aranha. O caráter grotesco destas formas, ao mesmo tempo disformes e horrendas, apenas nos pode causar desconforto e transmitir melancolia. A transformação do humano, no sentido da hibridez com o animal, manifesta a sua inconsistência e uma hemorragia permanente de sentido, de que a morte é a figura mais assustadora.

\subsection{A série televisiva Bones}

$\mathrm{Na}$ série televisiva Bones, a Cidade é um cadáver que a ciência inspeciona cuidadosamente. Retomando um esquema de Gilbert Durand e operando uma mitanálise da narrativa, Bones decorre entre o regime noturno do crime, que compreende sofrimento e morte, e o regime diurno da ciência e dos investigadores criminais, uma bem-aventurança que nos pacifica, enxotando as nossas sombras e dúvidas. Bones é tributária de um imaginário diurno, porque aí encontramos o herói solar, que desmascara os culpados e lança na cadeia os culpados. O herói é um anjo que julga em verdade e é o nosso medianeiro no esclarecimento dos crimes que produzem sofrimento e morte. Esse herói resolve, de um modo infalível, através de um conjunto de operações lógico-dedutivas, as situações mais sinuosas e perigosas. Tudo o que ensombra o local de um crime, ou então um quarto de prostituta, ou ainda um cadáver carbonizado, é uma noite que deve ser reconduzida à ordem do discurso da distinção solar.

Nietzsche assinala, na Segunda Intempestiva, que a ciência histórica não tem nada que esclarecer aquilo que nos é dado num estado de confusão. O que ela tem que fazer é de o respeitar. No entanto, em Bones, tanto os cientistas como os agentes policiais, uns e outros, modelos de retidão intelectual e moral, a clarificação e a distinção diurnas representam uma purificação, para não dizer uma purga: trata-se da singularidade clara e distinta dos objetos, que são depurados de qualquer ambiguidade, subjectividade ou relatividade. A clareza e a distinção na análise pretendem vencer a impureza, múltipla e abundante, que carateriza o regime noturno do crime, que é o do 
sofrimento e da morte. No entanto, o discurso da ciência não é o discurso da linguagem comum. De tão tecnicizado, é um discurso mágico, uma linguagem cifrada, a desempenhar a mesma função do latim, nas liturgias cristãs de outros tempos. A linguagem tecnocientífica é hoje, com efeito, um discurso soteriológico, o discurso do único messianismo que nos resta, um messianismo sem telos - a tecnologia.

\subsection{Representações da morte na programação televisiva}

Confirmando os resultados do estudo mais abrangente de Felisbela Lopes et al. (2009), o estudo realizado por Nuno Brandão (2010) conclui que a categoria "acidentes e catástrofes" é hegemónica nas notícias de abertura do telejornal (ano 2000/2001), nos três canais privados generalistas da televisão portuguesa, representando cerca de $20 \%$ do total, que compreende um conjunto de dez categorias para cada um dos três canais.

\begin{tabular}{|c|c|c|c|c|}
\hline & & RTP 1 (\%) & SIC (\%) & TVI (\%) \\
\hline \multirow{10}{*}{ 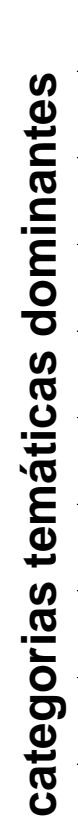 } & Acidentes e Catástrofes & 20,88 & 20,33 & 18,68 \\
\hline & Problemas Sociais & 7,14 & 14,84 & 16,48 \\
\hline & Estado / Política Internacional & 18,68 & 13,19 & 12,09 \\
\hline & Desporto & 9,89 & 9,34 & 12,64 \\
\hline & Saúde e Ciência & 5,49 & 8,24 & 7,69 \\
\hline & Tribunais & 5,49 & 8,24 & 9,34 \\
\hline & Assuntos Militares e Policiais & 12,09 & 5,49 & 8,24 \\
\hline & Guerras e Protestos & 6,04 & 4,4 & 3,85 \\
\hline & Partidos Políticos & 2,75 & 1,1 & 2,2 \\
\hline & Outros & 11,54 & 14,84 & 8,79 \\
\hline & Total & 100 & 100 & 100 \\
\hline
\end{tabular}

Resultados de um estudo realizado por Nuno Brandão (2010) sobre as aberturas dos telejornais portugueses

\subsection{Representações da morte nas notícias sobre a infância}

As notícias sobre a infância representam apenas cerca de 3\% das notícias da imprensa. Mas 65\% dessas notícias dizem respeito a situações de risco. Em consequência, a natureza dessas notícias indicia sempre sofrimento, e muitas vezes morte: abusos e maus tratos (físicos e psicológicos, sexuais, etc.), abandono, processos judiciais, acidentes e problemas de segurança, raptos, vadiagem, assaltos, pedofilia. 15\% de notícias sobre crianças em risco fazem capa de jornal. E um estudo feito sobre 
representações da infância na TV portuguesa, relativo a 2008, concluiu que 4\% das notícias repertoriadas fizeram a abertura do telejornal (Oliveira et al., 2010).

\section{De uma condição pacificada a uma condição atormentada}

Quando nos debruçamos sobre os mitos, os ritos, a iconografia e as crenças que temos a respeito do corpo morto, é de uma homenagem ao morto que falamos. Ou seja, do que se trata, sempre, é do cerimonial indispensável a garantir ao morto um futuro post mortem, um futuro que lhe permita escapar ao nada. Mas a sua função principal é de ordem terapêutica. Se não curativa, sem dúvida paliativa, ou melhor, reconfortante. Através do simbólico, procuramos curar, ou então prevenir a angústia dos sobreviventes, dos ainda vivos, que deste modo se reconfortam e negoceiam o sem sentido da morte. O simbólico é o recurso de uma sociedade organizada pela palavra. Os mitos, os ritos e os ícones constituem o regime simbólico de uma comunidade. Os mitos são falas, narrativas que organizam duravelmente as práticas de uma comunidade, dado exprimirem e concretizarem as suas crenças. E a mesma coisa se passa com os ritos, que constituem uma gestualidade estruturada e articulada com os mitos, exprimindo e concretizando também as suas crenças e organizando da mesma forma, no tempo longo, as suas práticas. As crenças e as superstições, que se exprimem por mitos, ritos e ícones, são atos simbólicos, que totalizam a vida de uma comunidade. As crenças constituem para a comunidade aquilo que as superstições constituem para os indivíduos.

As práticas simbólicas tradicionais, próprias das sociedades tradicionais, aproximam nascimento e morte (no caso das comunidades cristãs, aproximam batismo e funeral), o que corresponde a uma antropologia primordial destas culturas. Entretanto, com a supressão do Dies irae e dos ornamentos negros, e com o acento colocado nos laços que unem os vivos aos mortos e os vivos entre si, a simbólica da morte foi inteiramente colocada sob o signo da esperança e da pacificação.

As representações da morte na cultura visual contemporânea, quais rituais laicos de velar o corpo morto, declinam sobretudo as nossas atuais vertigens, em concomitância com o actual movimento de civilização de translação para o número, a imagem, a emoção e o múltiplo. Organizam-nas, pois, mais a dia/bolé (imagens que separam) que o sun/bolé (imagens que reúnem).

Concluindo este ensaio, podemos perguntar-nos, todavia, como é que passámos da ideia de harmonia, que presidia à teoria da identidade (harmonia do indivíduo), por um lado, e à ideia de cidadania (harmonia cívica), por outro, à conceção de um ente múltiplo (híbrido), fragmentado, um ente com identificações várias, e não definitivas, 
instável, viscoso, labiríntico e enigmático. Podemos perguntar-nos como é que passamos a esta perceção do humano como uma realidade hostil a todo o conhecimento definitivo, estável e grave. Convocando de novo Bakhtin (1970: 19), podemos dizer que esta perceção, "hostil a tudo o que está pronto e acabado, hostil a toda a pretensão ao imutável e ao eterno, necessita para se afirmar de formas de expressão mutáveis, flutuantes e móveis”. Por essa razão, as formas dramáticas, clássicas e sublimes devieram, como o assinalei já, trágicas, barrocas e grotescas.

A ideia de harmonia tinha na tradição ocidental um logos, de ideias ditas em verdade, um pathos, ordenado pela síntese redentora do logos, e um ethos, constituído por formas elevadas e valores superiores, definidos pelo logos, que orientava a ação. Por sua vez, a civilização técnica e mediática, dessacralizada e laica, tem um pathos dominante, onde sensações, emoções e paixões desativam a centralidade do logos e do ethos.

1. Na sociedade tradicional, o logos identifica-se com o estilo clássico das formas de pensamento, que são superfícies lisas, formas lógicas, de premissas claras, que concluem o certo e o verdadeiro. Predomina na sociedade tradicional a ideia de tempo como linha reta, decorrente do princípio teleológico, de orientação para um fim, pelo que a história se desenvolve entre uma génese e um apocalipse, que nos garante um fundamento sólido, um território conhecido e uma identidade estável.

O logos totaliza a existência e cria a unidade. A imaginação é a "folle du logis", que nos desordena, como se lhe referiram Descartes e Malebranche.

Na sociedade tecnológica e mediática, o logos é barroco. As formas são exuberantes, confusas e rugosas, conformes à natureza de um ente híbrido, ambivalente e desassossegado. Predominam na sociedade tecnológica e mediática as linhas curvas do tempo, as suas dobras e as superfícies côncavas, preenchidas por sombras.

O barroco instaura um regime de fluxos, que exprime a fragmentação da existência, a multiplicidade do indivíduo e a sua ambivalência.

A imaginação é agora a "fée du logis", que nos reencanta, como dela disse Gilbert Durand.

2. Na sociedade tradicional, o pathos é dramático - supõe uma síntese redentora. Ou seja, aqui o logos, que é a instância última e soberana de decisão, controla e orienta o pathos. Em contrapartida, na sociedade tecnológica e mediática o pathos é trágico. 
Com a existência a ser convertida em sensação, emoção e paixão, o trágico é agora a forma dominante do imaginário.

Esta dialética é passional e meramente tensional, pois nenhuma síntese a redime. Também não existe aqui identidade; a dialética tensional convoca identificações várias. E porque é a irrupção do não-lógico no humano, a forma trágica desconsidera o logos.

3. Na sociedade tradicional, o ethos casa com as formas sublimes: apela para valores elevados, superiores, coloca-se ao serviço de um absoluto, o dever-ser. Na sociedade tradicional, a ética da cidadania serve a comunidade humana, opondo-se ao individualismo.

$\mathrm{Na}$ sociedade tecnológica e mediática, o ethos é grotesco: inverte a hierarquia de valores, rebaixa os valores tradicionais, fazendo equivaler todas as categorias - impõe o relativismo, ou seja, o "politeísmo dos valores" (Weber), contra o dogmatismo do dever-ser. Nestes novos tempos, a morte de Diana de Gales, Madre Teresa, João Paulo II, Ayrton Sena, Miklos Fehér, Michael Jackson, equivalem-se e podem permutar-se.

O ethos é governado pelo pathos (pela sensação, pela emoção e pela paixão). Ou seja, impõe-se a "ética da estética" (aésthesis significa emoção), como assinala Michel Maffesoli (1990), e impõe-se o tribalismo, que é uma comunidade emocional. O presente, ou seja, o quotidiano, é deste modo o lugar onde se decide o humano. Neste sentido, o instante é a eternidade realizada, para retomar ainda uma bela fórmula de Maffesoli (2000).

\section{Referências bibliográficas}

AA.VV. (2007) Que valores para este tempo? (Actas de Conferência na Fundação Gulbenkian, Lisboa, 25-27 de Outubro de 2006), Lisboa: Fundação Gulbenkian \& Gradiva.

Agamben, Giorgio (2000) [1978], Enfance et Histoire. Paris: Payot \& Rivages.

Ariès, Philippe (1977) L'homme devant la mort. Paris: Seuil.

Ariès, Philippe (1975) Essais sur l'histoire de la mort en occident du moyen âge à nos jours. Paris: Editions du Seuil.

Augé, Marc (Dir.) (1995) La mort et moi et nous. Paris: Textuel.

Bakhtin, Mikhaïl (1970) L'oeuvre de François Rabelais et la culture populaire au Moyen Age et sous la Renaissance. Paris: Gallimard. 
Barthes, Roland (1942) "Culture et tragédie. Essais sur la culture". http://www.analitica.com/bitblio/barthes/culture.asp (consultado em 10 de Fevereiro de 2010).

Bastos, Cristiana \& González Alfredo (1996) "Cravado na pele, o hospital. Fronteiras do corpo em dias de Sida”, Vale de Almeida, Miguel (Org.) Corpo Presente. Oeiras: Celta, pp. 184-199.

Baudrillard, Jean (1996/1997) [1976] A troca simbólica e a morte. Lisboa: Edições 70.

Baudrillard, Jean (1981) Simulacres et Simulation. Paris: Galilée.

Bauman, Zygmunt (2003) [1995], La vie en miettes. Cahors: Editions du Rouergue.

Benjamin, Walter (2005) [1933] "Experiência e pobreza", Revista de Comunicação e Linguagens, 34: 317-321.

Benjamin, Walter (2004) [1927] A origem do drama trágico alemão. Lisboa: Assírio \& Alvim.

Blumenberg, Hans (1990) Naufrágio com espectador. Lisboa: Vega.

Brandão, Nuno (2010) As notícias nos telejornais, Lisboa: Guerra \& Paz.

Calabrese, Omar (1987) A Idade Neobarroca. Lisboa: Edições 70.

Cordeiro, Edmundo (1999) "Técnica, mobilização e figura. A técnica segundo Ernest Jünger”. Revista de Comunicação e Linguagens, 25/26.

Dayan, Daniel \& Katz, Elihu (2003) Televisão e Públicos no Funeral de Diana. Coimbra: Minerva (Org. de Mário Mesquita).

Debord, Guy (1991) [1967] A sociedade do espectáculo. Lisboa: Mobilis in Mobile.

Gauchet, Marcel (1985) Le désenchantement du monde. Paris: Gallimard.

Gonçalves, Albertino (2009) Vertigens. Para uma sociologia da perversidade. Coimbra: Grácio Editor.

Jeudy, Henri-Pierre (1990) Le désir de catastrophe. Paris: Aubier.

Jünger, Ernest (1990) [1930] La mobilisation totale, in L'Etat Universel - suivi de La mobilisation totale. Paris: Gallimard.

Lopes, Felisbela et alii (2009) "A notícia de abertura do TJ ao longo de 50 anos (19592009)”. Comunicação e Sociedade, 15. Húmus/CECS: Universidade do Minho, pp. 103126.

Lyotard, Jean-François (1993) Moralités post-modernes. Paris : Galilée.

Maffesoli, Michel (2000) L’instant éternel. Le retour du tragique dans les sociétés postmodernes. Paris: Denoël. 
Maffesoli, Michel (1990) Au creux des apparences. Pour une éthique de l'esthétique. Paris : La Table Ronde.

Marinho, Sandra (2007) “A queda da ponte de Entre-os-Rios”, in Pinto, M. \& Sousa, H. (Org.) Casos em que o jornalismo foi notícia. Porto: Campo das Letras, pp. 163-184.

Martins, Moisés de Lemos (2011) Crise no castelo da cultura - Das estrelas para os ecrãs, Coimbra, Grácio Editor.

Martins, Moisés de Lemos (2010) "A mobilização infinita numa sociedade de meios sem fins”, Álvares, Cláudia \& Damásio, Manuel (Org.) Teorias e práticas dos media. Situando o local no global. Lisboa : Edições Lusófonas.

Martins, Moisés de Lemos (2009) "Ce que peuvent les images. Trajet de l'un au multiple”, Les Cahiers Européens de l'Imaginaire, CNRS, 1: 158-162.

Martins, Moisés de Lemos (2002a) "O trágico como imaginário da era mediática". Comunicação e Sociedade n. 4, Universidade o Minho.

Martins, Moisés de Lemos (2002b) "O Trágico na Modernidade" [versão inglesa: “Tragedy in Modernity”]. Interact, Revista online de Arte, Cultura e Tecnologia, n. 5. http://www.interact.com.pt

Marzano, Michela (2007) La mort spectacle. Enquête sur l' "horreur-réalité". Paris: Gallimard.

Nietzsche, Friedrich (1988) [1887] Genealogia da Moral. São Paulo: Companhia das Letras.

Oliveira, Madalena (2008) "Sensibilidade mas com bom senso. Tratamento informativo da dor”, in Pinto, M. \& Marinho, S. (Org.) Os media em Portugal nos primeiros cinco anos do século XXI. Porto: Campo das Letras, pp. 213-225.

Oliveira, Madalena (2005) "Olhando a morte dos outros". Actas do 4. ${ }^{\circ}$ SOPCOM, Universidade de Aveiro. http://www.bocc.ubi.pt/pag/oliveira-madalena-olhandomorte-outros.pdf

Oliveira, M.; Pereira, S.; Ramos, R.; Martins, P. C (2010) "Depicting childhood in TV: analysis of children's images in news bulletins". Comunicação apresentada no $3^{\circ}$ Congresso Europeu da ECREA - European Communication and Education Association, Universidade de Hamburgo, Alemanha, 12-15 de Outubro

Oliveira, Maria Manuel (2007) In memoriam, na cidade, tese de doutoramento em arquitectura, Universidade do Minho. Repositorium UM http://hdl.handle.net/1822/6877

Perniola, Mario (2004) [1994], O Sex Appeal do Inorgânico. Ariadne: Lisboa.

Perniola, Mário (1993) [1991] Do Sentir. Lisboa: Presença.

Saraiva, Clara (1996) "Diálogos entre vivos e mortos", Vale de Almeida, Miguel (Org.) Corpo Presente. Oeiras: Celta, pp. 172-183. 
Sloterdijk, Peter (2000) La mobilisation infinie. Christian Bourgois Ed.

Sodré, Muniz \& Paiva, Raquel (2002) O império do grotesco. Rio de Janeiro: Ed. Mauad.

Sophia de Mello Breyner (1962) «Procelária», in Poesias do livro Geografia (I, II, III). www.maricell.com.br/sophiandresen/sophia17.htm

Terrain, 20, La Mort. Carnets du Patrimoine Ethnologique, Ministère de la Culture et de la Communication.

Thomas, Louis-Vincent (1985). Rites de mort. Paris: Fayard.

Torres, Eduardo Cintra (2007), "11 de Setembro: As quatro fases do evento mediático", in Pinto, M. \& Sousa, H. (Org.) Casos em que o jornalismo foi notícia. Porto: Campo das Letras, pp. 17-46.

Toscani, Oliviero (2007) A publicidade é um cadáver que nos sorri. Ediouro.

Vidal, Bertrand (2012) Les représentations collectives de l'évènement-catastrophe. Étude sociologique sur les perurs contemporaines. Thèse de doctorat présentée et soutenue à l’Université Montpellier III - Paul Valéry.

Virilio, Paul (2009) [1980] The aesthetics of disappearance. Los Angeles: Semiotext(e).

Virilio, Paul (2001) “Entretien avec Paul Virilio”, Le Monde de l’Education, 294: 135138.

Virilio, Paul (1995) Vitesse de libération. Paris: Galilée.

Wölfflin, Heinrich (1991) Renacimiento y barroco. Barcelona: Paidós.

Ziegler, Jean (1975) Les vivants et la mort. Paris: Seuil.

www.alexandermcqueen.com/

http://www.olivierotoscani.com/

Série televisiva americana - Bones. Criada por HartHanson para a Fox Network. Website: http://www.fox.com/bones/

Moisés de Lemos Martins é Professor Catedrático do Departamento de Ciências da Comunicação da Universidade do Minho (UM) e Director do Centro de Estudos de Comunicação e Sociedade (CECS) da mesma universidade.

moiseslmartins@gmail.com 